\title{
Effect of Nutrient Management Practices and Varieties on Yield, NPK Uptake, Quality and Soil Properties in Linseed (Linum usitatissimum L.)
}

\author{
Nitin Sood*, Pankaj Chopra, S. S. Rana and Naveen Datt \\ Department of Agronomy, CSK Himachal Pradesh Agriculture University, Palampur, \\ Himachal Pradesh, India \\ *Corresponding author
}

\section{A B S T R A C T}

\section{Keywords}

INM, Organic, Natural farming,

Nutrient

management,

Varieties, Yield,

Uptake, Oil and

Linseed

\section{Article Info}

Accepted:

04 November 2020

Available Online:

10 December 2020
A field experiment was conducted on a silty clay loam soil (acidic in reaction and medium in available NPK) during Rabi 2018-19 at Palampur to study the influence of nutrient management practices (Inorganic (RDF), Organic, Natural and Integrated) and varieties ('Him Palam Alsi-2', 'Himani' and 'Priyam') on yield, uptake, quality and soil properties in linseed. Results, revealed that among different nutrient management practices, Integrated Nutrient Management being at par with inorganic practice resulted in significantly higher seed, straw, uptake of NPK and oil yield. However, INM practice being at par with organic has significant advantage over inorganic practice for enhancing microbial count (i.e. bacteria, fungi and actinomycetes) and Microbial Biomass Carbon at harvest with 7.53 per cent increase in seed yield. After the harvest of the crop, significantly higher available nitrogen and phosphorus in soil was recorded under integrated and inorganic. However, INM resulted in significantly highest available potassium in soil. Among varieties, 'Him Palam Alsi-2' superseded all other varieties with significantly highest seed, straw, uptake of NPK and oil yield. Soil properties (i.e. microbial and available NP\&K at harvest) were not influenced due to varieties.

\section{Introduction}

Linseed [Linum usitatissimum (L.)] occupies a greater importance among oilseeds, owing to its various uses and special qualities. In present situation, linseed is gaining importance as a functional food. Recent advances in medical research have found linseed as best herbal source of Omega-3 fatty acid ( $\alpha$-linolenic acid) and lignan which have immense nutritional/medicinal effect on human body system (Touré and Xueming,
2010). In addition, linseed has high content of other health promoting substances such as soluble and insoluble fibre, complete carbohydrates, proteins, vitamins and minerals (Genser and Morris, 2003). Conventional agricultural practices which lead to increase in the productivity of crops also lead to soil health deterioration, environmental degradation and human health hazards. Considering the harmful effects of indiscriminate use of inorganic agriculture, there is need to find out alternative practices 
which are safe, sustainable and economically viable. As is low nutrient requiring crop, linseed can be well suited under organic, natural farming and Integrated Nutrient Management practices. Natural Farming (NF) is low-input, climate-resilient type of farming that encourages farmers to use low cost locally-sourced inputs, eliminating the use of artificial fertilisers and industrial pesticides (Prasada, 2016; Kumar, 2012). Organic farming is another production system which avoids or largely excludes the use of synthetic fertilizers, pesticides, growth regulators and livestock feed additives. In organic farming, organic manures (solid and liquid) like vermicompost, FYM, vermiwash, biofertilizers etc. are used (Stockdale et al., 2001; Alabadan et al., 2009). Also, for better utilization of resources and to produce crops with less expenditure, INM is other best approach in which combined use of organic and inorganic sources of plant nutrient not only pushes the production and profitability of crops, but also helps in maintaining the permanent fertility status of the soil (Krishnakumar et al., 2013).

As different nutrient sources are used in these management systems, which have different impact on crop productivity and soil properties like physical, chemical \& biological, thus need to be assessed. Moreover, varieties respond differently to different nutrient management practices because of their genetic characters along with environmental conditions. Thus, there is need to test the response of these newly evolved varieties under different nutrient management practices.

\section{Materials and Methods}

The experiment consisting of twelve treatments comprising of four nutrient management practices (Inorganic (RDF), Organic, Natural and Integrated) in main plots and three varieties viz. 'Him Palam Alsi-2', 'Himani' and 'Priyam' in sub plots was conducted in split plot design with three replications at experimental farm of Linseed unit, Department of Genetics and Plant Breeding, CSK Himachal Pradesh Krishi Vishvavidyalaya, Palampur during Rabi 2018-19. The soil of experimental field was having was silty clay loam in texture, acidic in reaction and medium in available nitrogen, phosphorus and potassium. The total rainfall received during the crop period was $613 \mathrm{~mm}$. Crop varieties as per treatments were sown at a distance of $22.5 \mathrm{~cm}$ apart rows by using 40 $\mathrm{kg} / \mathrm{ha}$ of seed. In inorganic nutrient management, recommended dose of fertilizers i.e. 50:40:20 N, $\mathrm{P}_{2} \mathrm{O}_{5}$ and $\mathrm{K}_{2} \mathrm{O}$ were used. In organic nutrient management practice, application of FYM @10 t/ha + seed inoculation with Azotobacter and PSB +2 sprays of Vermiwash at 30 and 45 DAS were done. In Natural farming nutrient management practice, seed treatment with Beejamrit + addition of sieved FYM @ 2.5q/ha with Ghanjeevamrit 2.5@ q/ha (Basal) + 5 foliar sprays of Jeevamrit @ 1:10 +1 foliar spray of fermented butter milk and mulching were done. While, in INM practice, seed inoculation with Azotobacter and PSB + 75\% NPK application through inorganic nutrient sources $+25 \% \mathrm{~N}$ through FYM was done.

The crop was harvested manually with the help of sickles from the net plot area, dried and threshed manually with wooden sticks. The seeds and stalk were separated and yields were expressed in $\mathrm{kg} / \mathrm{ha}$. Nitrogen and phosphorus content in seed and straw samples collected at harvest was determined through method given by Jackson, 1973 and potassium by Black, 1965. The calculated nitrogen, phosphorus and potassium content in seed and straw samples of a treatment was multiplied with seed and straw yield of that particular treatment to obtain uptake of 
respective nutrient. For determining available NPK $(\mathrm{kg} / \mathrm{ha})$ in soil after harvest of crop, the representative oven dried soil samples taken from $0-15 \mathrm{~cm}$ depth were processed by following analytical procedures suggested by Subbiah and Asija, 1956; Olsen et al., 1954 and AOAC, 1970, respectively. At harvest, soil samples collected from the rhizosphere of the soil profile for counting microbial load (i.e. for population of soil bacteria, fungi and actinomycetes) were subjected to standard serial dilution plate count method using Nutrient agar for bacteria, Krustose agar for actinomycetes and Rose Bengal agar for fungi (Wollum, 1982). Microbial biomass carbon was determined by fumigation - extraction method (Vance et al., 1987). The oil content in seeds was determined by the method given in A.O.A.C. using ether as solvent. Total oil yield on hectare basis was worked out by multiplying seed yield ( $\mathrm{kg} / \mathrm{ha}$ ) with oil percent present in seeds of respective treatment.

\section{Results and Discussion}

\section{Seed and straw yield}

Data presented in Table 1 revealed that seed and straw yield of linseed was significantly influenced by different nutrient management practices and varieties. Among nutrient management practices, significantly higher seed and straw yield was recorded in integrated nutrient managed plots. However, nutrient management through inorganic sources (RDF) was also statistically at par to it for these aspects. Nutrient management through organics being at par with inorganic management was found to be significantly superior over natural farming nutrient management for seed yield. For straw yield it followed the above said nutrient management practices. Lowest seed and straw yield was recorded in natural farming nutrient management practice. Although both the nutrient management practices i.e. integrated and inorganic were at par to each other but the percent increase in the seed and straw yield with integrated nutrient management was 7.53 and 8.32 per cent over inorganic practice.

The corresponding increase with this particular nutrient management practice was 18.17 and 34.98 per cent for seed yield and 24.32 and 34.26 per cent for straw yield, over organic and natural farming practice, respectively. The highest seed and straw yield under this treatment seems to be due to more dry matter, number of yield contributing characters like primary \& secondary branches per plant and capsules per plant, which contributed in getting significantly higher seed and straw yield of linseed. Results explained above are in close conformity with the finding of Husain et al., (2010); Sharma and Dayal (2005) in linseed.

Among varieties 'Him Palam Alsi-2' surpassed all other varieties for seed and straw yield, which was followed by 'Himani'. The variety 'Priyam' had significantly lowest seed yield. 'Him Palam Alsi-2' had 10.64 and 30.09 per cent higher seed yield and 12.72 and 23.77 per cent higher seed yield over 'Himani' and 'Priyam', respectively.

\section{Microbial population and Microbial biomass carbon}

Significantly higher microbial count i.e. bacterial, fungal, actinomycetes and total microbial biomass carbon were recorded in organic nutrient management practice. However integrated nutrient management practice was at par to it for all these microbiological parameter. This might be due to the fact that application of organic manures helped in increasing organic carbon content of soil which acted as carbon and energy sources for microbes in organic and integrated nutrient management practices and resulted in 
quick build-up of microflora and fauna. With respect to count of fungal population, nutrient management practice through natural farming was also at par to these two said practices. Significantly lowest count of bacteria and actinomycetes was recorded in inorganic nutrient management practice (RDF).

Microbial count and total microbiological biomass carbon were not influenced by varieties (Table 1).

\section{NPK uptake by crop}

Nutrient management practices and varieties have significant influence on nutrient uptake by seed and straw of linseed (Table 2). Among nutrient management practices, integrated nutrient management behaving statistically similar to inorganic management through RDF had significantly higher NPK uptake by both seed and straw of linseed. Better availability of nutrients in integrated nutrient management led to increase growth and higher dry matter accumulation of the crop and thereby increased nutrient uptake by increasing the seed and straw yield of linseed, as the nutrient uptake is the function of nutrient content and dry matter (seed + straw) yield of the crop.

These practices were followed by organic management for all the nutrients in seed and straw, except potassium in straw where natural farming nutrient management practice was also at par to it. Natural farming nutrient management practice was found to be significantly inferior for nutrients uptake in straw and seed.

Among varieties, significantly higher uptake of NPK in seed and straw was done by 'Him Palam Alsi-2', however variety 'Himani' was also at par to it for recording significantly higher uptake of phosphorus in seed and uptake of N, P and $\mathrm{K}$ in straw.

Table.1 Effect of nutrient management practices and varieties on seed \& straw yield and microbiological count \& Microbial Biomass Carbon in soil in linseed

\begin{tabular}{|c|c|c|c|c|c|c|}
\hline \multirow[t]{2}{*}{ Treatment } & \multicolumn{2}{|c|}{ Yield (kg/ha) } & \multicolumn{3}{|c|}{$\begin{array}{l}\text { Microbiological population }\left(\times 10^{4} \mathrm{CFU} \mathrm{g}^{-1}\right. \\
\text { soil) }\end{array}$} & \multirow[t]{2}{*}{$\underset{\left(\mu \mathrm{g} \mathrm{g}^{-1}\right)}{\mathrm{MBC}}$} \\
\hline & $\begin{array}{l}\text { Seed } \\
\text { yield }\end{array}$ & $\begin{array}{l}\text { Straw } \\
\text { yield }\end{array}$ & $\begin{array}{c}\text { Bacterial } \\
\text { population }\end{array}$ & $\begin{array}{c}\text { Fungal } \\
\text { population }\end{array}$ & $\begin{array}{l}\text { Actinomycetes } \\
\text { population }\end{array}$ & \\
\hline \multicolumn{7}{|c|}{ Nutrient management practices } \\
\hline Inorganic (RDF) & 1101.5 & 2320.9 & 14.6 & 60.8 & 54.6 & 121.6 \\
\hline Organic & 1002.3 & 2022.3 & 16.7 & 68.1 & 60.4 & 131.1 \\
\hline Natural farming & 877.5 & 1872.5 & 15.8 & 65.3 & 62.6 & 125.7 \\
\hline Integrated & 1184.5 & 2514.1 & 16.4 & 67.7 & 58.8 & 128.6 \\
\hline $\mathrm{CD}(\mathrm{P}=\mathbf{0 . 0 5})$ & 106.98 & 282.88 & 0.80 & 3.73 & 2.45 & 7.28 \\
\hline \multicolumn{7}{|l|}{ Varieties } \\
\hline Him Palam Alsi-2 & 1169 & 2429.5 & 16.1 & 64.3 & 57.9 & 125.7 \\
\hline Himani & 1056.5 & 2155.2 & 16.3 & 65.7 & 58.7 & 125.0 \\
\hline Priyam & 898.6 & 1962.8 & 15.2 & 66.5 & 60.7 & 130.4 \\
\hline $\mathrm{CD}(\mathrm{P}=\mathbf{0 . 0 5})$ & 47.75 & 139.89 & NS & NS & NS & NS \\
\hline
\end{tabular}


Table.2 Effect of nutrient management practices and varieties on nutrient uptake, available nutrient and oil content $\&$ yield of linseed

\begin{tabular}{|c|c|c|c|c|c|c|c|c|c|c|c|}
\hline \multirow[t]{4}{*}{ Treatment } & \multirow{2}{*}{\multicolumn{6}{|c|}{ Nutrient uptake (kg/ha) }} & \multirow{2}{*}{\multicolumn{3}{|c|}{$\frac{\text { Available Nutrient }}{\text { (kg/ha) }}$}} & \multirow{4}{*}{$\begin{array}{c}\text { Oil } \\
\text { content } \\
(\%)\end{array}$} & \multirow{4}{*}{$\begin{array}{c}\text { Oil } \\
\text { yield } \\
(\mathrm{kg} / \mathrm{ha})\end{array}$} \\
\hline & & & & & & & & & & & \\
\hline & \multicolumn{2}{|c|}{$\mathbf{N}$} & \multicolumn{2}{|c|}{$\mathbf{P}$} & \multicolumn{2}{|c|}{$\mathbf{K}$} & \multirow[t]{2}{*}{$\mathbf{N}$} & \multirow[t]{2}{*}{$\mathbf{P}$} & \multirow[t]{2}{*}{$\mathbf{K}$} & & \\
\hline & $\overline{\text { Seed }}$ & $\overline{\text { Straw }}$ & Seed & $\overline{\text { Straw }}$ & $\overline{\text { Seed }}$ & $\overline{\text { Straw }}$ & & & & & \\
\hline \multicolumn{12}{|c|}{ Nutrient management practices } \\
\hline $\begin{array}{l}\text { Inorganic } \\
\text { (RDF) }\end{array}$ & 66.9 & 43.4 & 7.1 & 10.9 & 21.0 & 40.2 & 234.7 & 24.7 & 133.9 & 32.6 & 350.0 \\
\hline Organic & 61.1 & 37.8 & 5.2 & 7.9 & 18.8 & 31.0 & 239.7 & 22.7 & 126.8 & 34.3 & 319.2 \\
\hline $\begin{array}{l}\text { Natural } \\
\text { farming }\end{array}$ & 54.1 & 32.3 & 4.8 & 5.9 & 13.3 & 27.3 & 229.1 & 21.8 & 123.8 & 33.1 & 270.3 \\
\hline Integrated & 69.2 & 46.8 & 6.4 & 11.5 & 22.8 & 37.7 & 243.3 & 23.5 & 145.4 & 33.7 & 379.6 \\
\hline $\mathrm{CD}(\mathrm{P}=0.05)$ & 4.01 & 5.13 & 0.94 & 1.74 & 2.19 & 4.09 & 8.98 & 1.92 & 8.97 & NS & 33.88 \\
\hline \multicolumn{12}{|l|}{ Varieties } \\
\hline $\begin{array}{l}\text { Him Palam } \\
\text { Alsi-2 }\end{array}$ & 66.5 & 42.3 & 6.1 & 9.6 & 21.1 & 38.0 & 233.6 & 22.5 & 130.6 & 33.1 & 378.3 \\
\hline Himani & 62.7 & 39.9 & 6.2 & 9.4 & 17.8 & 34.1 & 237.2 & 23.2 & 132.4 & 34.2 & 320.6 \\
\hline Priyam & 59.3 & 38.0 & 5.4 & 8.2 & 18.0 & 30.1 & 239.2 & 23.8 & 134.4 & 33.0 & 290.5 \\
\hline $\mathrm{CD}(\mathrm{P}=0.05)$ & 2.81 & 2.42 & 0.61 & 1.16 & 1.50 & 5.35 & NS & NS & NS & NS & 33.36 \\
\hline
\end{tabular}

Available nutrients in soil

Integrated nutrient management remained at par with inorganic fertilization through RDF resulted in significantly higher available nitrogen and phosphorus in soil after crop harvest, while it was significantly superior among all nutrient management practices for available potassium in soil. Nutrient management through organic practice also behaved statistically similar to above said two practices for available nitrogen in soil but followed these practices for higher available potassium in soil. With respect to available potassium in soil, organic management being at par with inorganic followed integrated nutrient management practice resulted in significantly higher availability of this nutrient in soil after the harvest of linseed crop. Lowest available nitrogen, phosphorus and potassium in soil were recorded in plots where nutrient management was done through natural farming (Table 2).

However in context to varieties, there was no significant influence on available nitrogen, phosphorus and potassium in soil at harvest of the crop.

\section{Oil content and yield}

It is evident from the data presented in Table 2 that different nutrient management practices and varieties were failed to influence the oil content of linseed significantly, however oil yield was affected significantly by both factors. Among different nutrient management practices, integrated nutrient being at par with inorganic (RDF) resulted in significantly higher oil yield. This was followed by organic which was statistically comparable to inorganic (RDF). Significantly lowest oil yield was recorded in natural farming nutrient management practice. The integrated nutrient management had 8.45, 18.92 and $40.43 \%$ higher oil yield over inorganic, organic and natural farming practice of nutrient management, respectively. Husain et $a l$. , (2010) also reported high oil yield in linseed with integrated nutrient management practice.

Among varieties, 'Him Palam Alsi-2' had the significantly highest oil yield and followed by 
'Himani'. Variety 'Him Palam Alsi-2' had 17.99 and 30.22 percent more oil yield as compared to 'Himani' and 'Priyam' varieties of linseed, respectively. As oil yield is the multiple of oil content and seed yield so the effects were reflected in the same way as that of seed yield due to particular treatment.

\section{References}

Alabadan, B.A., Adeoye, P.A. and Folorunso, E.A.,. 2009. Effects of different poultry wastes on physical, chemical and biological properties of soil. Caspian Journal of Environmental Sciences, 7: 31-35.

AOAC., 1970. Methods of analysis. Association of Official Agricultural Chemists, Washington, D.C. Edn., 3(13): 185.

Black, C.A., 1965. Method of soil analysis. Current Science, 25: 259-260.

Genser, A.D. and Morris, N.D., 2003. History of cultivation and uses of flaxseed. In: Flax -The genus (Linum usitatissimum L.). Taylor and Francis, London.

Husain, K., Chandra, R., Dubey, S.D., Kerkhi, S.A., Singh, K. and Saxena, M., 2010. Response of linseed (Linum usitatissimum L.) to INM modules. Progressive Agriculture, 10(3): 32-35.

Jackson, M.L., 1973. Soil Chemical Analysis. Prentice Hall Inc. Englewood Cliffs, New Jersey, USA.

Krishnakumar, S., Kannan, R.L. and Dhivya, M.M., 2013. Integrated Nutrient Management - A Review. LAP Lambert Academic Publishing, U.S.

Kumar, N., 2012. Subash Palekar's zero budget no-till rice farming.

Olsen, S.R, Cole, C.V., Watanabe, F.S. and
Dean, L.A., 1954. Estimation of available phosphorus in soil by extraction with $\mathrm{NaHCO}_{3}$. United States Department of Agriculture Circular, 939: 19-33.

Prasada, S., 2016. Campaign to reduce use of chemical fertilizers pesticides". The Hindu

Sharma, V.K. and Dayal, B., 2005. Response of linseed to organic and inorganic sources of nitrogen. Indian Journal of Agricultural Research, 39(4): 269-274.

Stockdale, E.N., Lampkin, N.H. and Hovi., 2001. Agronomic and environmental implications of organic farming systems. Advances in Agronomy, 70: 261-327.

Subbiah, B.V. and Asija, C.L., 1956. A rapid procedure for the estimation of available nitrogen in soil. Current Science, 25: 258-260.

Touré, A. and Xueming, X.U., 2010. Flaxseed Lignans: Source, biosynthesis, metabolism, antioxidant activity, bioactive components and health benefits. Comprehensive Reviews in Food Science and Food Safety, 9: 261-269.

Vance, E.D., Brookes, P.C. and Jenkinson, D.S., 1987. An extraction method for measuring soil microbial biomass carbon. Soil Biology and Biochemistry, 19: 703-707.

Wollum, A.G., 1982. Cultural methods for soil microorganism. In: Methods of soil analysis part II chemical and microbiological properties. $2^{\text {nd }}$ edition, American Society of Agronomy, Soil Science Society of America. Inc. Publisher, Madison, Wisconsin USA., 781-813.

\section{How to cite this article:}

Nitin Sood, Pankaj Chopra, S. S. Rana and Naveen Datt. 2020. Effect of Nutrient Management Practices and Varieties on Yield, NPK Uptake, Quality and Soil Properties in Linseed (Linum usitatissimum L.). Int.J.Curr.Microbiol.App.Sci. 9(12): 250-255.

doi: https://doi.org/10.20546/ijcmas.2020.912.033 